\title{
Nestor Nyžankivskyj, ukrajinský žák Vítězslava Nováka
}

\section{Nestor Nyzhankivsky, Ukrainian Pupil of Vítězslav Novák}

\author{
Petr Ch. Kalina / 17113@mail.muni.cz \\ Department of Musicology, Faculty of Arts, Masaryk University, Brno, CZ
}

\begin{abstract}
The study provides the basic biographical data and evaluation of the work of a West Ukrainian composer and pianist Nestor Nyzhankivsky (1893-1940), who was educated in music in Lviv and Vienna. Afterwards, he studied in the composition master class of the Czech composer and music teacher Vítězslav Novák at the Prague Conservatoire from 1923 to 1928. He also worked in Prague as a teacher of music theory subjects at the Mykhailo Drahomanov Ukrainian Higher Pedagogical Institute until 1929. After returning to Lviv, he became an important part of the local music scene. He composed, performed as a pianist and taught piano and music theory subjects at the Higher Musical Institute of Mykola Lysenko. Furthermore, he reflected the local music scene as a music critic. From 1934, he was a head of the Union of Ukrainian Professional Musicians. After the annexation of the Eastern Galicia to the Soviet Union, he left his homeland and died in an emigration camp in Lodz, Poland. His compositional work is characterized as a synthesis of the romantic tradition with the tendencies of the modernism and contains the piano and vocal compositions primarily.
\end{abstract}

\section{Key words}

Nestor Nyzhankivski, Vítězslav Novák, Ukrainian music, interwar Czechoslovakia, Prague Conservatory 
V mistrovských kompozičních tř́ídách Vítězslava Nováka a Josefa Suka studovalo několik umělců ze západní Ukrajiny, kteří se po návratu do vlasti stali důležitými osobnostmi kulturního života východní Haliče v oblasti artificiální hudby. Vedle Vasyla Barvinského, jenž navštěvoval soukromé kompoziční lekce u Vítězslava Nováka ještě před první světovou válkou, jsou to zejména Mykola Kolessa, Zenovij Lysko a Nestor Nyžankivskyj, kteří ve 30. letech 20. století pomohli pozvednout západoukrajinskou hudební kulturu na kvalitativně podstatně vyšší úroveň, než v jaké se nacházela v době monarchie, a to nejen jako skladatelé, nýbrž také coby interpreti, pedagogové a hudební publicisté. Většině ze zmíněných osobností jsme věnovali některé z našich předchozích textů, ${ }^{1} \mathrm{v}$ aktuální stati přinášíme českému čtenáři informace o skladateli a klavíristovi Nestoru Ostapovyčovi Nyžankivském² ${ }^{2}$ (1893-1940).

Tento syn vlastenecky uvědomělého řecko-katolického kněze a zároveň amatérského skladatele, sbormistra, sběratele lidových písní a zakladatele prvního notového vydavatelství v Haliči Ostapa Josypovyče Nyžankivského (1863-1919) a Oleny Bačynské (18681926) se narodil 31. srpna 1893 ve městě Berežany (polsky Brzeżany) v dnešní Ternopilské oblasti Ukrajiny. Národnostně smíšená východní Halič, kde toto místo leží, náležela v té době k předlitavské části Rakousko-uherské monarchie. O rok později po Nestorově narození se rodina přestěhovala do Lvova, kde Ostap Nyžankivskyj získal místo pěveckého pedagoga $\mathrm{v}$ učitelském semináři a na gymnáziu. Nestor pak prožil dětství a jinošství ve vesnici Zavadiv nedaleko Stryje v dnešní Lvovské oblasti, kde se jeho otec vrátil ke kněžské činnosti. Rodina Nyžankivských zde udržovala přátelské styky s významnými osobnostmi soudobého ukrajinského kulturního života, mezi něž patřil spisovatel a politik Ivan Franko, operní pěvkyně světového formátu Solomija Krušelnycka nebo skladatel a muzikolog Stanislav Ljudkevyč.

Nestor se od osmi let učil hrát na klavír a chodil zpívat do sboru stryjského Bojanu. Dle jeho vlastních slov na něj v dětství nejvíce působila díla světových romantiků, zejména Richarda Wagnera. ${ }^{3}$ Navštěvoval gymnázium ve Stryji, odkud však byl za účast na zakázaném plese v roce 1910 vyloučen, a tak si gymnaziální erudici doplnil ve Lvově. Během středoškolského studia krátce navštěvoval klavírní třídu na Vysokém hudebním ústavu Mykoly Lysenka, což mu nevyhovovalo a docházel pak raději do soukromých hodin mladého klavíristy Tarase Šuchevyče a později navštěvoval lekce u profesora Vídeňské hudební akademie Jerzyho Lalewicze, který jednou za dva týdny jezdil do Lvova učit. O vzdělávání u Šuchevyče Nestor Nyžankivskyj píše: „Byl to on, kdo mi jako proni otevřel oči, že se hudba musí brát vážně a že je potřeba těžce pracovat. Tehdy jsem na sobě pocítil

1 Kalina, Petr Ch.. Vasyl Barvinskyj, ukrajinský žák Vítězslava Nováka. Opus musicum 47, 2015, č. 1, s. 18-37; Kalina, Petr Ch.. Kolessa, Mykola Filaretovyč. In: Český hudební slovník osob a institucí. On-line [cit.: 2020-09-04] Dostupné z: https://www.ceskyhudebnislovnik.cz/slovnik/index.php?option=com_mdictionary\&task=record. record_detail\&id=1002094; Kalina, Petr Ch.. Zenovij Lysko, ukrajinský žák Josefa Suka. Opus musicum 49, 2017, č. 2, s. 25-41.

2 Jeho př́ijmení je v českých i ukrajinských pramenech často uváděno jako „Nyžankovskyj / Нижанковський“.

3 Нижанківський, Нестор. Автобіографія. In: Булка, Юрій: Нестор Нижанківський. Життл і твориістъ. Львів - Ню Йорк: М. Коць, 1997, s. 45. 
důsledky svědomité dřiny a začal jsem si věřit. Dál jsem komponoval jako samouk. " ${ }^{\text {Formou }}$ soukromého vyučování se také školil v hudební teorii u Stanislava Ljudkevyče a v harmonii u polského muzikologa Adolfa Chybińského. Po maturitě na lvovském gymnáziu v červnu 1912 narukoval Nyžankivskyj do IV císařského pěchotního pluku, nicméně kvưli neutěšenému zdravotnímu stavu byl za několik měsíců z vojenské služby uvolněn. Už na podzim téhož roku se tak mohl zapsat k řádnému studiu na právnické fakultě Lvovské univerzity, kde na něj mimo jiných pedagogicky působil významný ukrajinský historik a pozdější předseda ukrajinské Centrální rady Mychajlo Hruševskyj. Nestor Nyžankivskyj paralelně se studiem práv pokračoval v soukromém hudebním vzdělávání. Na radu ukrajinského tenoristy Modesta Mencinského, který získal slávu jako sólista zejména v německých operních domech, se Nyžankivskyj rozhodl věnovat se plně hudbě a z právnické fakulty odešel. ${ }^{5}$ Roku 1913 se zapsal ke studiu na filozofickou fakultu Lvovské univerzity na nově ustanovený obor muzikologie, kde se zejména u již zmíněného Adolfa Chybińského školil v teoretických i historických hudebněvědných disciplínách. Hudebně přeci jen provinciální Lvov mu však brzy začal být poněkud těsný. Tento pocit u něj ještě zesílil po návštěvě Mnichova, kde zhlédl některé Wagnerovy opery. ${ }^{6}$

Na začátku první světové války složil přijímací zkoušku do Vídeňské hudební akademie. Byl přijat k bezplatnému studiu hry na klavír u svého starého známého Jerzyho Lalewicze a na hudební teorii k Josephu Marxovi, který ho učil harmonii a kontrapunkt a inspiroval jej také jako skladatel. V březnu 1915 narukoval Nestor Nyžankivskyj do rakouské armády. Na východní frontě brzy upadl do ruského zajetí a následující tři roky prožil v internačních táborech. V zajetí se sice snažil komponovat některé vokální skladby (např. píseň Ne spivaj po vesni), v zásadě však po onu dobu umělecky stagnoval, což se dočasně projevilo na jeho psychické kondici. V květnu 1918 ze zajetí uprchl a uchýlil se ke své rodině do Zavadova. ${ }^{7} \mathrm{~V}$ listopadu téhož roku byla na území východní Haliče vyhlášena Západoukrajinská lidová republika, která si své právo na existenci musela vybojovat na obnoveném Polsku. Nestor Nyžankivskyj se spolu se svými bratry Stepanem a Bohdanem nechali naverbovat jako dobrovolníci Ukrajinské haličské armády. Jednou z mnoha obětí této ukrajinsko-polské války se stal jejich otec Ostap, který byl coby představitel Národní rady Západoukrajinské lidové republiky polskými vojáky ve Stryji zatčen a bez soudu zastřelen. ${ }^{8}$ V červenci 1919 se Nestor spolu s Ukrajinskou haličskou armádou dostal na východ do sousední Ukrajinské lidové republiky, kde začal působit jako sbormistr ve vinnyckém Sadovského hudebním divadle a u pěveckých těles organizovaných Ministerstvem tisku a propagandy Ukrajinské lidové republiky. Po nezdaru uchování nezávislosti obou ukrajinských státních útvarů se v roce 1920 vrátil do Vídně, aby završil svá hudební studia. Vinou střelného zranění na ruce, které během války utrpěl, se nemohl věnovat klavírní hře a soustředil se na studium kontrapunktu u Marxe. Závěrečnou

4 Ibid., překlad autora studie.

5 Булка, Юрій. Нестор Нижанківський. Життя і твориість. Львів - Ню Йорк: М. Коць, 1997.

6 Хибінський, Адольф. Спогади про Остапа і Нестора Нижанківських. In: Булка, Юрій: Heстор.Huжанківський. Життя і творчість. Львів - Ню Йорк: М. Коць, 1997, s. 52-53.

7 Булка, Юрій. Нестор Нижанківський. Життя і твориість. Львів - Ню Йорк: М. Коць, 1997.

8 Людкевич, Станіслав. Дослідення, статті, рещензї, виступи. Том 1. Львів: М. Коць, 1999. 
zkoušku s právem nastoupit do mistrovské kompoziční třídy složil v říjnu 1923. Paralelně studoval také na Vídeňské univerzitě, kde ještě v červenci 1923 promoval jako doktor filosofie v oboru Dějiny východní Evropy. Za dobu vídeňských studií zkomponoval několik klavírních skladeb (Fuga na téma BACH, Preludium a fuga c moll na ukrajinské téma, Velké variace fis moll, miniatury Kolomyjka a $Z$ mého deniku) ${ }^{9}$ a písně (Žyta na slova Oleksandra Olese, dodnes velmi populární skladatelova vzpomínka na ruské zajetí Zasumuj trembito na slova Romana Kupčynského, Der Herbst ist da a Wozu bin ich erwacht na texty Melaniji Semaky, s níž se ve Vídni oženil). ${ }^{10}$

Na doporučení svého staršího kolegy, skladatele Oleksandra Barvinského, ${ }^{11}$ jenž před první světovou válkou studoval soukromě u Vítězslava Nováka, se Nestor Nyžankivskyj roku 1923 odstěhoval do Prahy, kde nalezl množství svých krajanů i řadu ukrajinských emigrantských institucí a tím pádem také poměrně snadnou možnost uplatnění. Byl rozhodnut završit zde své hudební vzdělání v mistrovské kompoziční třídě Vítězslava Nováka na pražské konzervatoři. Nedlouho po příjezdu do Prahy však navštívil představení Novákovy opery Lucerna a dle svědectví Vasyla Barvinského pochyboval, že bude schopen se svým učitelem najít společnou uměleckou řeč, jelikož se mu Novák zdál „př́liš moder$n \imath^{*}$. Brzy po zahájení studia však začal Nyžankivskyj s Novákovým kompozičním stylem souznít a stal se jeho ideovým přívržencem. ${ }^{12}$ Vítězslav Novák oceňoval značné skladatelské nadání svého žáka a Nyžankivského pokroky zhodnotil následovně: „Pracoval svědomitě, nakolik mu trvalá jeho choroba dovolovala, o svém zdokonaleni. Nejjistějším cítil se ve skladbě klavirni, čehož di̊kazem jsou jeho Variace na ukrajinskou píseň. Rovněž klavírni trio s tématikou v duchu národnim jest psáno v ryzím komorním slohu a velmi pěkně zní. Potěšitelný pokrok $v$ technice orchestrálni vykazuje letos napsaná Polonéza. Jest si práti, aby mu zdravotni stav umožnil intenzíuněji pracovati, protože jeho nadání je nesporné. "13 Choroba, o níž se Vítězslav Novák zmiňuje, byla kloubní tuberkulóza v levém koleně, ${ }^{14}$ která Nestora Nyžankivského trápila po zbytek života. Vinou tohoto onemocnění se tříleté vyučování v mistrovské třídě Nyžankivskému protáhlo na pět let. Studium u Nováka nakonec absolvoval v roce 1928. ${ }^{15}$ Kromě skladeb, o kterých Novák ve svém posudku píše, vznikly v Praze Nyžankivského klavírní kompozice Pochod fis moll jako součást Velkých variací na ukrajinské lidové téma, Odpověd' na pohled z Madridu, Malá suita, Vzpominka, dále smíšený sbor a cappella Haločka na slova Mychajla Obidného a další dvě sborové skladby, o nichž bude řeč níže. Jeho diplomovou prací bylo Klavirni trio e moll, které zaznělo 23. června 1928 v sále Umělecké

9 Барвінський, Василь. Вступне слово про життя і творчість Нестора Нижанківського. In: Булка, Юрій. Нестор Нижанківсъкий. Життя і творчість. Львів - Ню Йорк: М. Коць,, 1997, s. 47-51.

10 Людкевич, Станіслав. Дослідження, статті, рещензї, виступи. Том 2. Львів: М. Коць, 2000.

11 Павлишин, Стефанія. Львівські музиканти і «празька школа». In: Союз украӥнсъких професійних музик у Львові. Матеріали і документи. Львів: Сполом, 1997, s. 15-18.

12 Барвінський, Василь. Вступне слово про життя і творчість Нестора Нижанківського. In: Булка, Юрій. Нестор Нижанківсъжий. Життя і творчість. Львів - Ню Йорк: М. Коць, , 1997, s. 47-51.

13 Kubáň, Josef. Vítězslav Novák a pražská konzervatoř. In: Národni umělec Vítězslav Novák. Studie a vzpomínky k 100. výročí narození. Jihočeské muzeum České Budějovice 1972, s. 195-196.

14 Archiv Slovanské knihovny v Praze, fond T-Drah, inv. č. 59 - Personálie - lektoři, zaměstnanci: Nyžankivskyj, Nestor, r. 1925-1930.

15 ВБ [Барвінський, Василь]. 3 успіхів молодих украӥнсъких музиків у Празі. Діло, 16. 8. 1928, ч. 181 , s. 4. 
besedy a potom také 4. dubna 1929 v královéhradeckém divadle na ukrajinské hudební akademii na počest Tarase Ševčenka a Ivana Franka. ${ }^{16}$ Otakar Šourek jako recenzent absolventského koncertu (na němž mj. byly uvedeny také diplomové skladby Mykoly Kolessy, Alexandra Moyzese a Dalibora Vačkáře) charakterizoval na stránkách deníku Venkov Nyžankivského skladbu následovně: „Dílem, jenž přes autorovo mládi nese podivuhodné znaky umělecké zralosti, bylo klavirni trio Nestora Nyžankovského z mistrovské školy Novákovy. Majic v práci všechnu poctivost této školy, je to skladba myšlenkově vzácně svěžího a výrazného obsahu, jehož hodnoty stoupaji od věty $k$ větě, aby přes vášnivě rozezpivanou píseñ smutku dospěly vrcholu ve větě poslední, v ryze slovanských rytmech vervně roztančené a rozradostněné. Dílo nesporně velkého talentu, jenž už něco umí."17

Na živobytí v Praze si Nestor Nyžankivskyj vydělával výukou na Hudebně-pedagogickém oddělení Ukrajinského vysokého pedagogického ústavu Mychajla Drahomanova. Na této vysoké škole určené ukrajinským emigrantům působil po celou dobu svého pražského pobytu, tedy v letech 1923-1929. Pracoval na katedře hudební teorie a kompozice nejprve jako lektor, později coby docent a jeho zadáním byla výuka hudebně teoretických předmětů. ${ }^{18}$

Na Drahomanovově ústavu byl činný také jako klavírista hojně účinkující na akademiích a slavnostních koncertech, které tento jeho zaměstnavatel pořádal, i na dalších akcích. Nyžankivskyj se tak významnou měrou podílel na podobě hudebního života ukrajinské diaspory v Československu. Jeho sbor Huljaly na slova Jurije Fed'kovyče zazněl ve výstavním sále Vysoké školy zemědělské v Brně 18 . března 1922 (tedy ještě před příjezdem z Vídně do Prahy) na tradičním ševčenkovském večeru. ${ }^{19}$ Nyžankivského osobní účast je doložená na koncertu 6. prosince 1923 k připomenutí památky Mykoly Lysenka v pražském Obecním domě, ${ }^{20}$ dále o šest dní později na večeru k uctění dvacetileté tvůrčí činnosti ukrajinského básníka působícího v Praze Oleksandra Olese ve velkém sálu na Žofíně, ${ }^{21}$ na koncertu u příležitosti sedmého výročí vyhlášení nezávislé Ukrajiny 22. ledna 1925 v sále Národního domu na Smíchově, ${ }^{22}$ na koncertním večeru k 25 . výročí od úmrtí Zdeňka Fibicha 25. listopadu 1925 ve Studentském domově Na Slupi, kde interpretoval větu Jo a Jupiter z Fibichova klavírního cyklu Malírské studie a doprovázel ústavní smíšený sbor. ${ }^{23} 16$. června 1926 participoval na koncertu studentů Drahomanovova ústavu složeného z jeho skladeb a také kompozic kolegy Zenovije Lyska; ${ }^{24}$ 18. prosince

16 Булка, Юрій. Нестор Нижанківський. Життл і твориість. Львів - Ню Йорк: М. Коць, 1997.

17 O. Š. [Šourek, Otakar]. Výstupní zkoušky pražské konzervatoře. Venkov 23, 8. 7. 1928, č. 161, s. 8.

18 Kalina, Petr Ch.. Hudebně-pedagogické oddělení Ukrajinského vysokého pedagogického ústavu Mychajla Drahomanova v Praze (1923-1933). Musicologica Brunensia 54, 2019, č. 1, s. 223-236.

19 Národní archiv Praha. Fond Ukrajinské muzeum, inv. č. 1014.

20 Ibid., inv. č. 1019.

21 Ibid., inv. č. 1014.

22 Ibid.

23 Archiv Slovanské knihovny v Praze, fond T-Drah, inv. č. 404 - Pozvánky, oslavy, akademie, r. 1925.

24 Беєль [Барвінський, Василь]. Кониерт з творів З. Лисъка й Н. Нижанківсъкого. Діло, 28. 7. 1926, ч. 164, c. 2 . 
téhož roku hrál v sále Hlaholu vlastní klavírní skladbu Vzpominka; ${ }^{25}$ 19. prosince 1927 doprovázel svou píseň Zasumuj trembito:26 24. ledna 1928 řídil a doprovázel nastudování opery Nokturn Mykoly Lysenka ${ }^{27}$ a 19. prosince v tomtéž roce uvedl na koncertě k výročí pěti let existence Drahomanovova ústavu svou klavírní Fantasii. ${ }^{28}$ Jeho Smyčcové trio a píseň Mynuly lita molodi byly provedeny na koncertě 15 . května $1929 \mathrm{v}$ sále Hlaholu u prŕiležitosti 68. výročí od úmrtí ukrajinského básníka Tarase Ševčenka, kde účinkoval také jako doprovazeč. ${ }^{29}$

Nyžankivského angažmá na vysoké škole pojmenované podle významného ukrajinského politika a literáta souvisí se vznikem jeho skladby pro smíšený sboru s barytonovým sólem Poklyk do brativ slavjan nazývaným někdy též podle svého incipitu Hej ne dyvujte, který má v autorově tvưrčím dědictví významné postavení. Nestor Nyžankivskyj v něm v roce 1924 zhudebnil část vlastenecky angažované básně Mychajla Drahomanova, od jehož úmrtí mělo v následujícím roce uplynout 30 let. V dopise z 31. ledna 1929 napsal skladatel akademickému senátu svého zaměstnavatele, že této škole věnuje autorská práva na onu kompozici jako výraz vděku za to, že mu na její půdě byla dána možnost pracovat v oblasti hudby rodného národa.$^{30}$ Dílo zaznělo 19. prosince 1925 v Obecním domě na drahomanovovské akademii, o rok později 18. prosince v sále Hlaholu ${ }^{31}$ a 30 . ledna 1929 na místě, které není doloženo. ${ }^{32}$ V roce 1932 vyšla skladba tiskem v Praze. ${ }^{33}$ Jiným Nyžankivského „zaměstnaneckým dílem“ pro Drahomanovův ústav je kantáta Šče moloda pro smíšený sbor a cappella na slova Oleksy Stefanovyče, v níž autor cituje jak melodii ukrajinské hymny Šče nevmerla Ukrajina, tak i českou hymnu Kde domov můj. ${ }^{34}$

I na tomto akademickém pracovišti komplikovala kloubní tuberkulóza Nestoru Nyžankivskému život. V archivu Ukrajinského vysokého pedagogického ústavu, který uchovává Slovanská knihovna Národní knihovny ČR, nacházíme několik dopisů Nestora Nyžankivského svému zaměstnavateli, v nichž opakovaně žádá o prodloužení dovolené za účelem léčení v lázních Bojnické Kúpele, což dokládá lékařským potvrzením. Na škole Nyžankivskyj pracoval do konce roku 1929, kdy mu byla schválena neplacená dovolená na dobu od 1. prosince 1929 do 31. srpna 1930 a odjel „do Haliče a Bukoviny za účelem vědecké práce

25 Archiv Slovanské knihovny v Praze, fond T-Drah, inv. č. 405 - Pozvánky, oslavy, akademie, r. 1926.

26 Ibid., inv. č. 406 - Pozvánky, oslavy, akademie, r. 1927.

27 Обідний, М.. Памяти М. Лисенка. Свято Украйнсвкого педагогічного інституту ім. М. Драгоманова в Празі. Діло, 17. 2. 1928, ч. 36, s. 2-3.

28 Archiv Slovanské knihovny v Praze, fond T-Drah, inv. č. 407 - Pozvánky, oslavy, akademie, r. 1928.

29 Ibid., inv. č. 408 - Pozvánky, oslavy, akademie, r. 1929.

30 Ibid., inv. č. 59 - Personálie - lektoři, zaměstnanci: Nyžankivskyj, Nestor, r. 1925-1930.

31 Národní archiv Praha. Fond Ukrajinské muzeum, inv. č. 1014.

32 Archiv Slovanské knihovny v Praze, fond T-Drah, inv. č. 408 - Pozvánky, oslavy, akademie, r. 1929.

33 Нижанковський, Нестор. Із вірша М. Драгоманова «Поклик до братів славян» «Гей не дивуйтесь» на мішаний хор а капела. In: Прахі Украӥнсъкого високого педагогічного інституту ім. Михайла Драгоманова у Празі. Драгоманівський збірник. Прага: Сіяч 1932, s. 125-134.

34 Соневицький, Ігор. Композиторська спадщина Нестора Нижанківського. In: Записки Наукового товариства імені Т. Шевченка. Том ССХХVI. Праиі Музикознавчої комісї., Львів: Наукове товариство імені Т. Шевченка у Львові, 1993, s. 334-352. 
v odvětvi ukrajinské hudby. “35 Do Československa se však už nevrátil, jelikož Ukrajinský vysoký pedagogický ústav Mychajla Drahomanova prožíval finanční krizi, která vyvrcholila zastavením jeho činnosti v roce 1933, a tak musel pracovní poměr s Nyžankivským ukončit.

Další životní i umělecké osudy našeho skladatele a klavíristy už s Československem spojeny nejsou. Je doloženo, že jeho klavírní skladba Maličká suita zazněla ještě 13. ledna 1931 na oslavách 60. narozenin Vítězslava Nováka v Mozarteu na večeru složeném z kompozic jeho zahraničních žáků. ${ }^{36}$ Nyžankivského šestileté působení v Praze bylo sice epizodní, na jeho tvưrčí zrání i na podobu západoukrajinské hudební kultury však mělo podstatný vliv.

Ještě v době jeho pražského pobytu se Nyžankivského díla začala čím dál častěji uvádět ve Lvově a díky klavíristce Ljubce Kolessa se s nimi v letech 1927-1929 mohlo seznámit i publikum na naddněperské Ukrajině, tedy v Sovětském svazu. ${ }^{37}$ Po návratu do vlasti se Nyžankivskyj usadil opět ve Lvově a zásluhou Vasyla Barvinského získal místo pedagoga na Vysokém hudebním ústavu Mykoly Lysenka, který byl později po zabrání západní Ukrajiny Sovětským svazem přeměněn na Lysenkovu konzervatoř. Nestor Nyžankivskyj zde učil klavírní hru a hudebně teoretické předměty jako je kontrapunkt, hudební formy, intonace a organologie.

V období svého obnoveného lvovského působení napsal Nyžankivskyj několik sborových skladeb (mezi nimi rozsáhlý patrioticky laděný smíšený sbor a cappella s mezzosopránovým sólem Najmyt na slova Ivana Franka), písní a klavírních kompozic, ale také první orchestrální díla (symfonická Polonéza zkomponovaná v Praze, jíž zmiňuje Vítězslav Novák, se nedochovala) jako je Pohřebni pochod pro symfonický orchestr, který byl věnován 10. výročí smrti někdejšího předsedy direktoria Ukrajinské lidové republiky Symona Petljury a pro lvovský kulturní spolek Prosvita Pochod instrumentovaný pro dechový orchestr. V této době také vznikla do dnešních dnů nedochovaná hudba ke hře Jurije Kosače Kyrka z Loleo abo Lvivska spokusnycja (premiéra roku 1938 ve Lvově). Další dílo větší formy - smíšený sbor s doprovodem symfonického orchestru na slova Jurije Fed’kovyče Radujsja, Marije - zůstalo nedokončeno. ${ }^{38}$

Kromě toho Nyžankivskyj ve Lvově a okolí vystupoval v koncertních sálech i ve lvovském rozhlase jako klavírista. Zřejmě vinou starého válečného zranění ruky neúčinkoval př́liš často coby sólista, byl však velmi vyhledávaným doprovázečem pěvců i instrumentalistů. ${ }^{39}$ Proslulým se stalo zejména jeho vystoupení v červnu 1932 na recitálu sopranistky Solomije Krušelnycké, která měla v té době v západoevropských operních domech již vybudováno značné renomé. Nemálo úsilí věnoval Nestor Nyžankivskyj také hudební

35 Archiv Slovanské knihovny v Praze, fond T-Drah, inv. č. 59 - Personálie - lektoři, zaměstnanci: Nyžankivskyj, Nestor, r. 1925-1930.

36 Národni osvobození, 17. 1. 1931, s. 4.

37 Козачук, О. С.. Мистеиъкий простір Нестора Нижанківського. До 120-річия від дня народження. Науковий часопис НРУ ім. М. П. Драгоманова. Серія 14: Теорія і методика мистецької освіти, 2014, вип. 16, s. $26-31$.

38 Барвінський, Василь. Нестор Нижанківський. Наші дні 1, 1941, ч. 2, s. 7-8.

39 Людкевич, Станіслав. Дослідженяя, статті, рещензї, виступи. Том 2. Львів: М. Коць, 2000. 
kritice. Reflektoval soudobé haličské hudební dění, zejména ukrajinské. V letech 19351938 byl pravidelným přispěvatelem novin Ukrajinski visti, v nichž každý týden shrnul a poučeným způsobem zhodnotil nejdůležitější hudební události Ukrajinců, ale i Poláků a Židů ve Lvově a okolí. ${ }^{40}$

Významným počinem pro haličské muzikanty ukrajinské národnosti bylo založení Svazu ukrajinských profesionálních hudebníků v dubnu 1934. Tuto instituci, která chránila profesní zájmy ukrajinských skladatelů, výkonných umělců, muzikologů i hudebních pedagogů a začala vydávat pionýrský hudební časopis Ukrajinska muzyka, spoluzaložili mimo Stanislava Ljudkevyče a dalších muzikantů také odchovanci pražské konzervatoře - kromě Nyžankivského to byli skladatelé Vasyl Barvinskyj, Mykola Kolessa a klavírista (absolvent mistrovské třídy Viléma Kurze) Roman Savyckyj. Nestor Nyžankivskyj stál od založení svazu do roku 1936 (kdy vyvrcholil dlouhotrvající konflikt mezi ním a Stanislavem Ljudkevyčem) a poté také v roce 1939 v jeho čele. Svaz rovněž vydával notové materiály svých členů i jiných skladatelů a tuto složku své činnosti započal edicí Nyžankivského pozoruhodného klavírního alba pro mládež, což byl mimochodem první zástupce tohoto žánru v dějinách ukrajinské hudby východní Haliče. Nestor Nyžankivskyj byl zároveň členem Muzikologické komise Vědecké společnosti Tarase Ševčenka, což byla instituce, která v Haliči plnila funkci ukrajinské akademie věd. ${ }^{41}$

Slibně se rozvíjející kulturní emancipace Ukrajinců vưči Polákům jakožto státnímu národu, v níž hrál Nestor Nyžankivskyj nikoliv bezvýznamnou roli, postupně přešla na kvalitativně zcela odlišnou úroveň zabráním Haliče a Volyně Sovětským svazem v září 1939 na základě tajného dodatku paktu Ribbentrop-Molotov. Politické a osobní občanské nastavení Nestora Nyžankivského odmítalo přijmout ideologicky výrazně zabarvená pravidla nového politického a společenského pořádku. Konečně, za jeho někdejší angažmá v Ukrajinské haličské armádě mu jako „nacionalistovi“ mohly v sovětském režimu hrozit persekuce.

Nyžankivskyj zjevně z pragmatických důvodů načas podlehl diktátu nového režimu. Svědčí o tom jeho podpis pod Pozdravem skladateli̊ západni Ukrajiny skladateliom Sovětského svazu, který vyšel v kyjevském časopise Rad’anska muzyka:

„Skladatelé západni Ukrajiny, kteři jsou členy Svazu ukrajinských profesionálních skladateli ve Lvově, s nadšením přivítali okamžik, kdy se za pomoci hrdinné osvobozujici Rudé armády spojili Ukrajinci a Bělorusové do jedné rodiny. Nyni nastal čas posilovat družbu lidu západní Ukrajiny pro společnou tvưrči práci na vybudováni kultury ukrajinské země osvobozené od panského Polska.

$V$ tyto historické dny vstupujeme do nového života a prohlašujeme, že jsme připraveni ke společné práci s našimi bratry skladateli Sovětského svazu a předáváme Vám vřelý pozdrav. Podle Vašeho přikladu budeme neúnavně pracovat $k$ dosaženi blaha veliké země Sovětů a jejiho statečného lidu.

40 Булка, Юрій. Нестор Нижанківський. Життя і творчість. Львів - Ню Йорк: М. Коць, 1997.

41 Штундер, Зеновія. Станіслав Людкевич. Життя і твориість. Том 1. Львів: БІНАР-2000, 2005. 


\section{Z pověreni Svazu skladateli západni Ukrajiny}

Dr. S. Ljudkevyč, prof. V. Barvinskyj, Dr. N. Nyžankivskyj“42

Brzy však Nyžankivskyj poznal, že situace je pro něj bezvýchodná. Využil skutečnosti, že byl držitelem rakouského pasu a spolu s manželkou se obrátil na německý emigrantský výbor, který v té době sídlil ve Lvově, a požádal jej o azyl v té části Polska, jež byla okupována německou armádou. 5. ledna 1940 se stal opět emigrantem. O málo později duševně otřesený skladatel v táboře vystěhovalců v polské Lodži těžce onemocněl spálou a 10. dubna 1940 ve věku 46 let v nemocnici zemřel. Předtím ještě stihl napsat svou poslední skladbu s výmluvným názvem - šlo o dodnes nedochovaný Pochod vystěhovalců pro mužský sbor a cappella na německý text své manželky. Melanija Semaka-Nyžankivska se po manželově smrti odstěhovala s jejich jediným synem, patnáctiletým Olehem do Prahy - do města, které bylo konečně synovým rodištěm a kde také žila Melanijina matka. Krátce po skončení druhé světové války byla Melanija Nyžankivska v Praze zatčena (zřejmě jednotkami Směrš) a ve stejné souvislosti byl nenávratně zničen celý rukopisný archiv jejího manžela. ${ }^{43}$ Melanija se poté odstěhovala do Belgie, kde zemřela v roce $1973 .{ }^{44}$

Po druhé světové válce sovětská hudební historiografie ani dramaturgové kulturních institucí dílo Nestora Nyžankivského téměř nepřipomínali, a tak tento umělec upadl postupně do zapomnění. Teprve v období „glasnosti“ se o Nyžankivském opět začalo mluvit a psát. V roce 1987 bylo ve Stryji založeno Muzeum rodiny Nyžankivských. Od roku 1992 se ve stejném městě pořádá Celoukrajnská soutěž mladých klavíristů, která nese Nyžankivského jméno. Roku 1993 inicioval skladatelův syn, barytonista Oleh, sólista Velkého divadla v Ženevě, přenesení ostatků svého otce z Lodže do Stryje a jejich uložení v sousedství hrobu skladatelových rodičů. ${ }^{45} \mathrm{~V}$ roce 2013 bylo ukrajinským parlamentem přijato usnesení, že 120. výročí od narození Nestora Nyžankivského bude v srpnu a září téhož roku formou nejrůznějších prostředků (televizní a rozhlasové pořady, vydání poštovní známky, odhalení pamětní desky na skladatelově rodném domě) připomenuto a financováno na celostátní úrovni. ${ }^{46}$

Dochované skladatelské dědictví Nestora Nyžankivského čítá pouze kolem 70 opusů a takřka u něj nenacházíme díla větších forem (většinu skladeb tvoří klavírní miniatury,

42 Citováno podle: Штундер, Зеновія. Станіслав Людкевич. Життя і твориість. Том 2., Жовква: Місіонер 2009, s. 6, překlad autora studie.

43 Соневицький, Ігор. Композиторська спадщина Нестора Нижанківського. In: Записки Наукового товариства імені Т. Шевченка. Том ССХХVI. Прачі Музикознавчої комісї., Львів: Наукове товариство імені Т. Шевченка у Львові 1993, s. 334-352.

44 Боробкевич, Тетяна. Присвяти Н. Нижанківського у «Фортепіанних творах для молоді». In: Нижанківський, Нестор: Твори для фортепіано. Українська фортепіанна музика, Львів 2019 [nestránkováno].

45 Булка, Юрій. Нестор Нижанківсъжий. Життл і твориість. Львів - Ню Йорк: М. Коць, 1997.

46 Проект постанови Верховної Ради України від 04.07.2013 р. N 2501а Про відзначення 120-річчя 3 дня народження Нестора Нижанківського On-line: [cit.: 2020-09-04] Dostupné z: https://ips.ligazakon.net/document/DG1XHA0I 
sbory a písně). Poměrně malý počet děl jistě souvisí se skutečností, že skladatel skonal ve středním věku, že byl po celý produktivní život sužován nevyléčitelnou nemocí a že pobyl tři roky v zajetí. Své profesní vzdělání završil až v 35 letech, kdy si jiní umělci obyčejně již užívají období tvưrčí zralosti (v této souvislosti není bez zajímavosti, že všichni jeho hudební učitelé - Lelewicz, Chybiński, Marx i Novák - zemřeli později než on). Za života Nestora Nyžankivského vyšlo jen málo jeho děl tiskem, tudíz se jeho skladby se zachovaly především v rukopise a opisech. O některých dílech víme, že existovala, resp. byla provedena, ale do dnešních dnů se nedochovala - ztratila se bud' už za skladatelova života, nebo byla později zničena $\mathrm{v}$ jeho pražském archivu. Ihor Sonevyckyj po dvacetiletém pátrání po Nyžankivského skladbách odhaduje, že nyní máme k dispozici přibližně $80 \%$ jeho díla. ${ }^{47}$

Absence rozměrnějších forem je u ukrajinských skladatelů východní Haliče až do konce druhé světové války běžným jevem. Velké hudební instituce jako je filharmonie nebo opera byly totiž ve Lvově v rukou Poláků, kteří mezi sebe Ukrajince zpravidla vůbec nepouštěli. Ukrajinci se ve své domovině kulturně emancipovali jen velmi pomalu, neměli takřka žádnou šanci na provedení vlastních orchestrálních nebo hudebně-dramatických děl, a tak se o vytváření těchto hudebních druhů ani nepokoušeli. Pokud západoukrajinští skladatelé v meziválečné době komponovali díla pro rozsáhlejší provozovací aparát, pak to bylo v cizině, kde existovala možnost, že bude dílo nastudováno (vokální symfonie Kavkaz Stanislava Ljudkevyče napsaná ve Vídni, orchestrální Ukrajinská suita, Passacaglia, scherzo a fuga a Variace na vlastni téma pro symfonický orchestr Mykoly Kolessy komponované v Praze apod.). V tomto ohledu získali hudebníci ukrajinské národnosti mnohem lepší podmínky po připojení Haliče a Volyně k Ukrajinské sovětské socialistické republice a Nyžankivského generační souputníci, kteří ve vlasti zůstali, začali skládat i velká díla stejně jako jejich krajané z naddněperské Ukrajiny. To však ze známých př́čin nebyl Nyžankivského př́ípad.

Jeho kompoziční styl bývá charakterizován jako syntéza romantické tradice s tendencemi hudební moderny. ${ }^{48}$ Celek Nyžankivského skladeb působí jako neustálé, avšak pozoruhodné tvưrčí hledání, jež nebylo z důvodu jeho předčasného skonu završeno. Je především lyrikem, což se projevuje nejen v instrumentálních dílech, ale i výběrem textů pro skladby vokální, nicméně, jak připomíná jeho životopisec Jurij Bulka, dovedl Nyžankivskyj vytvářet i epické, taneční, scherzózní, groteskní i dramatické obrazy. ${ }^{49}$ Teritoriálnímu kontextu hudebnímu kontextu východní Haliče se náš skladatel vymyká především výraznějším sklonem k polyfonii a místy i k rozšiřrené tonalitě, což je důsledkem jeho vídeňských studií. Charakteristickým rysem mnoha jeho skladeb je také zřetelný ukrajinský hudební kolorit, jehož nedosahuje přímými citacemi lidových písní nebo tanců (výjimkou jsou variace na ukrajinská lidová témata), nýbrž pozoruhodnou uměleckou stylizací s použitím typických melodických, metrických a strukturních elementů ukrajin-

47 Соневицький, Ігор. Композиторська спадщина Нестора Нижанківського. In: Записки Наукового товариства імені Т. Шевченка. Том ССХХVІ. Прачі Музикознавчої комісї., Львів: Наукове товариство імені Т. Шевченка у Львові 1993, s. 334-352.

48 Кияновська, Любов. Галицька музична культура XIX-XX cm, Чернівці: . Книги - XXI, 2007.

49 Булка, Юрій. Нестор Нижанківський. Життя і твориість. М Львів - Ню Йорк: М. Коць, 1997. 
ského folklóru, v čemž zase můžeme spatřovat pedagogický vliv Vítězslava Nováka. Pro Nyžankivského sborové skladby jsou typické značné nároky na interpretační dovednosti pěvců. $\mathrm{V}$ jeho vokálních dílech s klavírem neplní klavír roli pouhého doprovodného nástroje, nýbrž je rovnoprávnou součástí kompozice - rozsáhlejší klavírní intermezza nezřídka exponují nová hudební témata, která ve vokálním partu nenajdeme. Sám Nyžankivskyj svou tvorbu ještě ve 20. letech v Praze charakterizoval následovně: „Jsem lyrikem s velkou dávkou heroismu. Nejsem harmonik, spiše kontrapunktik. Trochu impresionista, ale vice melodik. [...] Donedávna jsem byl vokalista, postupně jsem se v̌̌ak přetvořil v instrumentalistu. Kam má cesta povede dál, nevím. "50

I přes poměrně skromný kompoziční odkaz talentovaného odchovance české hudební kultury můžeme o této osobnosti hovořit (zcela v souladu s ukrajinskou hudební historiografií) jako o důležitém západoukrajinském hudebníkovi. Jeho význam je totiž nutné vidět v dobovém a místním kontextu. Nyžankivskyj nemohl rozvíjet svůj talent tak dlouho jako ostatní významní lvovští skladatelé jeho doby (Vasyl Barvinskyj prožil 75 let, Stanislav Ljudkevyč 100 let a Mykola Kolessa dokonce 103 let) a jejich významu jistě nedosahuje. Přesto je jeho skladatelské dílo, jež je dnes trvalou součástí repertoáru ukrajinských koncertních sálů, i dobový význam jeho interpretační, pedagogické a hudebně-kritické činnosti podstatným příspěvkem k postupně se rozvíjející meziválečné hudební kultuře Ukrajinců v Haliči, která teprve po druhé světové válce mohla vystoupat na evropskou úroveň.

\section{Bibliography}

\section{Sources}

Archiv Slovanské knihovny v Praze, fond T-Drah, inv. č. 59 - Personálie - lektoři, zaměstnanci: Nyžankivskyj, Nestor, r. 1925-1930.

Archiv Slovanské knihovny v Praze, fond T-Drah, inv. č. 404 - Pozvánky, oslavy, akademie, r. 1925. Archiv Slovanské knihovny v Praze, fond T-Drah, inv. č. 406 - Pozvánky, oslavy, akademie, r. 1927. Archiv Slovanské knihovny v Praze, fond T-Drah, inv. č. 407 - Pozvánky, oslavy, akademie, r. 1928. Archiv Slovanské knihovny v Praze, fond T-Drah, inv. č. 408 - Pozvánky, oslavy, akademie, r. 1929. Národní archiv Praha. Fond Ukrajinské muzeum, inv. č. 1014.

Národní archiv Praha. Fond Ukrajinské muzeum, inv. č. 1019.

\section{Literature}

KALINA, Petr Ch. Hudebně-pedagogické oddělení Ukrajinského vysokého pedagogického ústavu Mychajla Drahomanova v Praze (1923-1933). Musicologica Brunensia 54, 2019, č. 1, s. 223-236. KALINA, Petr Ch. - KOLESSA, Mykola Filaretovyč. In: Český hudebni slovnik osob a institucí.

50 Нижанківський, Нестор. Автобіографія. In: Булка, Юрій. Нестор Нижанківсвкий. Життя $і$ твориість. Львів - Ню Йорк: М. Коць, 1997, s. 46, překlad autora studie. 
On-line [cit.: 2020-09-04] Dostupné z: https://www.ceskyhudebnislovnik.cz/slovnik/index.php?option=com_mdictionary\&task=record.record_detail\&id=1002094;

KALINA, Petr Ch. Vasyl Barvinskyj, ukrajinský žák Vítězslava Nováka. Opus musicum 47, 2015, č. 1, s. $18-37$.

KALINA, Petr Ch. Zenovij Lysko, ukrajinský žák Josefa Suka. Opus musicum 49, 2017, č. 2, s. 25-41. KUBÁŇ, Josef. Vítězslav Novák a pražská konzervatoř. In: Národni umělec Vitězslav Novák. Studie a vzpominky k 100. výroči narození. Jihočeské muzeum České Budějovice 1972, s. 195-196.

Národni osvobozeni, 17. 1. 1931, s. 4.

O. Š. [ŠOUREK, Otakar]. Výstupni zkoušky pražské konzervatoře. Venkov 23, 8. 7. 1928, č. 161, s. 8.

БАРВІНСЬКИЙ, Василь. Вступне слово про життя і творчість Нестора Нижанківського. In: Булка, Юрій. Нестор Нижанківський. Життя і твориість. Львів - Ню Йорк: М. Коць,, 1997, s. 47-51.

ВБ [БАРВІНСЬКИЙ, Василь]. 3 успіхів молодих украӥнсъких музиків у Празі. Діло, 16. 8. 1928, ч. 181, s. 4 .

Беєль [БАРВІНСЬКИЙ, Василь]. Конщерт з творів З. Лиська й Н. Нижанківського. Діло, 28. 7. 1926 , ч. 164 , с. 2.

БАРВІНСЬКИЙ, Василь. Нестор Нижанківсъкий. Наші дні 1, 1941, ч. 2, s. 7-8.

БОРОБКЕВИЧ, Тетяна. Присвяти Н. Нижанківського у «Фортепіанних творах для молоді». In:

Нижанківський, Нестор: Твори для фортепіано. Українська фортепіанна музика, Львів 2019.

БУЛКА, Юрій. Нестор Нижанківський. Життя і твориість. Львів - Ню Йорк: М. Коць, 1997.

КИЯНОВСЬКА, Любов. Галиџька музична культура XIX-XX cm, Чернівці: Книги - XXI, 2007.

КОЗАЧУК, О. С.. Мистещький простір Нестора Нижанківсъкого. До 120-річия від дня народження.

Науковий часопис НРУ ім. М. П. Драгоманова. Серія 14: Теорія і методика мистецької освіти, 2014, вип. 16, s. 26-31.

ЛЮДКЕВИЧ, Станіслав. Дослідженя, статті, рещензї, виступи. Том 1. Львів: М. Коць, 1999.

ЛЮДКЕВИЧ, Станіслав. Досліджння, статті, рещензї, виступи. Том 2. Львів: М. Коць, 2000.

НИЖАНКІВСЬКИЙ, Нестор. Автобіографія. In: Булка, Юрій. Нестор Нижанківський. Життя і твориість. Львів - Ню Йорк: М. Коць, 1997, s. 45.

НИЖАНКОВСЬКИЙ, Нестор. Із вірша М. Драгоманова «Поклик до братів славян» «Гей не дивуйтесь» на мішаний хор а капела. In: Праиі Украӥнського високого педагогічного інституту ім. Михайла Драгоманова у Празі. Драгоманівський збірник. Прага: Сіяч 1932, s. 125-134.

ОБІДНИЙ, М.. Памяти М. Лисенка. Свято Украӥнського педагогічного інституту ім. М. Драгоманова в Празі. Діло, 17. 2. 1928, ч. 36, s. 2-3.

ПАВЛИШИН, Стефанія. Львівські музиканти і «празька школа». In: Союз украйнських професійних музик у Львові. Матеріали і документи. Львів: Сполом, 1997, s. 15-18.

Проект постанови Верховної Ради України від 04.07.2013 р. N 2501a Про відзначення 120-річчя з дня народження Нестора Нижанківського On-line: [cit.: 2020-09-04] Dostupné z: https:// ips.ligazakon.net/document/DG1XHA0I

СОНЕВИЦЬКИЙ, Ігор. Композиторська спадщина Нестора Нижанківського. In: Записки Наукового товариства імені Т. Шевченка. Том ССХХИІ. Прачі Музикознавчої комісї, Львів: Наукове товариство імені Т. Шевченка у Львові, 1993, s. 334-352.

ШТУНДЕР, Зеновія. Станіслав Людкевич. Життя і твориість. Том 1. Львів: БІНАР-2000, 2005. ШТУНДЕР, Зеновія. Станіслав Людкевич. Життя і твориість. Том 2., Жовква: Місіонер 2009, s. 6. ХИБІНСЬКИЙ, Адольф. Спогади про Остапа і Нестора Нижанківських. In: Булка, Юрій. Нестор.Нижанківський. Життя і твориість. Львів - Ню Йорк: М. Коць, 1997, s. 52-53. 